\title{
Effects of an Inhibitor of the Gamma-Secretase Complex on Proliferation and Apoptotic Parameters in a FOXL2-Mutated Granulosa Tumor Cell Line (KGN) ${ }^{1}$
}

\author{
Griselda Irusta, ${ }^{3,4}$ Camila Pazos Maidana, ${ }^{3,4}$ Dalhia Abramovich, ${ }^{4}$ Ignacio De Zúniga, \\ Fernanda Parborell, ${ }^{4}$ and Marta Tesone ${ }^{2,4,6}$ \\ ${ }^{4}$ Instituto de Biologra y Medicina Experimental (IBYME-CONICET), Buenos Aires, Argentina \\ ${ }^{5}$ Centro Médico PREGNA Medicina reproductiva, Buenos Aires, Argentina \\ ${ }^{6}$ Departamento de Química Biológica, Facultad de Ciencias Exactas, Universidad de Buenos Aires, Buenos Aires, \\ Argentina
}

\begin{abstract}
Ovarian granulosa cell tumors (GCTs) represent $3 \%-5 \%$ of all ovarian malignancies. Treatments have limited proven efficacy and biologically targeted treatment is lacking. The aim of this study was to investigate the role of Notch signaling in the proliferation, steroidogenesis, apoptosis, and phosphatidylinositol 3-kinase (PI3K)/AKT pathway in a FOXL2-mutated granulosa tumor cell line (KGN) representative of the adult form of GCTs. When Notch signaling is initiated, the receptors expose a cleavage site in the extracellular domain to the metalloproteinase TACE and, following this cleavage, Notch undergoes another cleavage mediated by the presenilin-gamma-secretase complex. To achieve our goal, DAPT, an inhibitor of the gammasecretase complex, was used to investigate the role of the Notch system in parameters associated with cell growth and death, using a human granulosa cell tumor line (KGN) as an experimental model. We observed that JAGGED1, DLL4, NOTCH1, and NOTCH4 were highly expressed in KGN cells as compared to granulosa-lutein cells obtained from assisted reproductive techniques patients. The proliferation and viability of KGN cells, as well as progesterone and estradiol production, decreased in the presence of $20 \mu \mathrm{M}$ DAPT. Apoptotic parameters like PARP and caspase 8 cleavages, BAX, and BCLXs increased in KGN cells cultured with DAPT, whereas others such as BCL2, BCLXI, FAS, and FAS ligand did not change. AKT phosphorylation decreased and PTEN protein increased when Notch signaling was inhibited in KGN cells. We conclude that the Notch system acts as a survival pathway in KGN cells, and might be interacting with the PI3K/AKT pathway.
\end{abstract}

apoptosis, KGN cells, Notch system, PI3K/AKT signaling

\section{INTRODUCTION}

Ovarian granulosa cell tumors (GCTs) belong to sex cordstromal tumors and represent $3 \%-5 \%$ of all ovarian malignancies [1]. These tumors arise from granulosa cells and their

\footnotetext{
${ }^{1}$ Supported by the National Council for Scientific and Technical Research (CONICET-PIP1223), Universidad de Buenos Aires (979 and 20020090300061), and Roemmers Foundation (ANPCYT [PICT] 20100248; Argentina).

${ }^{2}$ Correspondence: Marta Tesone, Instituto de Biología y Medicina Experimental (IByME), Vuelta de Obligado 2490, C1428ADN Buenos Aires, Argentina. E-mail: martatesone.uba@gmail.com

${ }^{3}$ These authors contributed equally to this work.
}

Received: 21 January 2013.

First decision: 15 February 2013.

Accepted: 13 May 2013.

(C) 2013 by the Society for the Study of Reproduction, Inc.

elSSN: 1529-7268 http://www.biolreprod.org

ISSN: 0006-3363 malignant potential is due to their tendency to recur and metastasize. The probability of recurrence in GCT patients is rather high (35\%), and $80 \%$ of those with recurrent disease will die from it. Although GCTs are comprised of cells different from those of epithelial tumors, they are often treated the same, simply because GCTs are rare and there is little information available. Although these tumors contain both granulosa and theca cells, the malignant part arises from the granulosa component. GCTs are categorized into two distinct subtypes: the juvenile and the adult form. Little is known about the pathogenesis of ovarian GCTs. However, Shah et al. [2] have recently reported a somatic mutation in the FOXL2 gene (C402G; Cys134Trp), specifically present in $97 \%$ of adult GCTs. The presence of this mutation was later confirmed in several other publications [3-7], and subsequent studies confirmed its presence in adult GCTs and its absence in juvenile GCTs and other human malignancies [5, 8-11]. However, treatments have limited proven efficacy and biologically targeted treatment modalities are lacking.

The Notch system is an evolutionary conserved pathway involved in key developmental processes. In mammals, the Notch family of proteins consists of four receptors (NOTCH 14) and five ligands (JAGGED 1 and 2 and DELTA-like 1, 3, 4) expressed on the cell surface. When Notch signaling is initiated, the receptors expose a cleavage site in the extracellular domain to the metalloproteinase TACE and, following this cleavage, Notch undergoes another cleavage mediated by the presenilin- $\gamma$-secretase complex. This results in the release of the active intracellular domain, which translocates to the nucleus [12] and exerts pleiotropic effects by initiating a transcriptional cascade [13]. The Notch pathway is also involved in vascular maintenance and remodeling and is a key participant in tumor angiogenesis [14].

Several lines of evidence demonstrate that Notch is involved in several human cancers. In particular, high expression of Notch1 and Jagged1 in breast cancer is linked to poor survival rates, and Jagged 1 is highly expressed in metastatic prostate cancer as compared to localized or benign prostatic tissue [1517].

In particular, in ovarian cancer, the Notch signaling pathway has been found altered in $22 \%$ of 316 cases of high-grade serous ovarian adenocarcinomas analyzed [18]. Moreover, Jagged1 and Dl14 play important roles in tumor and endothelial compartments of ovarian cancer mouse models $[19,20]$. Nevertheless, the function of this novel Notch system in the adult form of GCTs remains unknown.

The phosphatidylinositol 3-kinase (PI3K)/AKT signal transduction pathway plays a critical role in cell survival through suppression of apoptosis in various types of human cancers, including ovarian cancer [21-24]. PI3K is an activator 
of AKT and has been proposed as a putative oncogen in ovarian cancer, because its activation has been associated with aggressiveness of the tumor behavior and decreased survival $[25,26]$. In addition, different reports have demonstrated the interaction between Notch signaling and PI3K/AKT pathways in breast cancer cells and prostate cancer cells [27, 28].

Based on these antecedents about the participation of Notch signaling in the behavior of a wide range of human cancers, including epithelial ovarian cancer, we speculated that this system might be involved in the regulation of cell survival and apoptosis in GCTs. To test this hypothesis, we used a granulosa tumor cell line (KGN) representative of the adult form of GCTs [5], and examined the expression of some Notch members and whether the inhibition of Notch signaling affects proliferation, steroidogenesis, and apoptotic parameters. Because it is known that the PI3K/AKT pathway is involved in ovarian cancer, we studied a possible interaction between this intracellular pathway and Notch signaling.

\section{MATERIALS AND METHODS}

\section{Reagents}

Antibodies against NOTCH1 (sc-6014-R), NOTCH4 (sc-9170), JAGGED1 (sc-8303), DLL4 (sc-28915), PARP (sc-7150), BAX (sc-493), BCLX (SC634), FAS (sc-715), FAS ligand (FASL) (sc-956), Caspase 8 (sc-7890), phospho-AKT (sc-7985) and actin B (sc-1616) were purchased from Santa Cruz Biotechnology, Inc. AKT (9272) antibody was from Abcam and monoclonal BCL2 (887) antibody was from Dako. Antibody against PTEN (phosphatase and tensin homolog) was purchased from Millipore, anti-rabbit secondary antibody (A-9414) from Sigma-Aldrich, and anti-mouse IgG horseradish peroxidase conjugate (HAF007) from R\&D Systems. All other chemicals were of reagent grade and were obtained from standard commercial sources.

\section{Culture of KGN and Obtaining of Human Granulosa-Lutein Cells}

The study was approved by the Research Ethics Committee of the Instituto de Biología y Medicina Experimental, Buenos Aires, Argentina. The tumor cell line (KGN) was kindly provided by Dr. H. Nawata, Kyushu University, Japan [29]. For the different experiment techniques, cells were cultured in Dulbecco modified Eagle medium (DMEM):F12 (1:1 vol/vol; Sigma) supplemented with $10 \%$ fetal bovine serum (FBS; PAA Laboratories), fungizone $(250 \mu \mathrm{g} / \mathrm{ml})$, and gentamicin $\left(10 \mathrm{mg} / \mathrm{ml}\right.$; Life Technologies, Inc.) with $5 \% \mathrm{CO}_{2}-95 \%$ air at $37^{\circ} \mathrm{C}$. KGN cells were characterized as a malignant tumor model of the adult form of GCTs [30].

For comparative purposes human granulosa-lutein cells (hGCs) were obtained from patients subjected to assisted reproductive techniques (ART). Written informed consent was obtained from all the patients before recruitment, and patients with pelvic pathologies such as endometriosis, uterine fibroids, or pelvic inflammatory disease were excluded from the study. Follicular fluid was collected during oocyte retrieval from nine patients attending PREGNA Institute of Reproductive Medicine (Argentina) for male and female infertility treatment, as previously described $[31,32]$. Briefly, follicular aspirates of each patient collected during oocyte retrieval were centrifuged at $400 \times g$ for $10 \mathrm{~min}$. After removing the supernatant, the layers of hGCs with the red blood cell pellet were resuspended in $2 \mathrm{ml}$ of DMEM:F12 $(1: 1 \mathrm{vol} / \mathrm{vol})$ containing $10 \mathrm{mM}$ HEPES supplemented with fungizone $(250 \mu \mathrm{g} / \mathrm{ml})$ and gentamicin $(10 \mathrm{mg} / \mathrm{ml}$; Life Technologies, Inc.) in a sterile 50-ml centrifuge tube. The resuspended pellet was layered carefully on Percoll cushion (density $=1.085,3 \mathrm{ml} \mathrm{Percoll} /$ $\mathrm{ml}$ cell suspension; Sigma-Aldrich) in $15-\mathrm{ml}$ sterile tubes and centrifuged at $600 \times g$ for $30 \mathrm{~min}$. Granulosa-lutein cells were aspirated from the interface, resuspended, and observed under an optic microscope. Finally, the pellet was stored at $-70^{\circ} \mathrm{C}$ for protein extraction.

For the study of apoptotic parameters in KGN cells, $2 \times 10^{5}$ cells per well were seeded in six-well tissue culture plates maintained in DMEM containing $10 \% \mathrm{FBS}$. After $24 \mathrm{~h}$ of culture, the medium was removed and fresh medium containing $2 \%$ FBS with or without DAPT (N-[N-(3,5-difluorophenacetyl-Lalanyl)]-S-phenylglycine $t$-butyl ester; Sigma-Aldrich) $20 \mu \mathrm{M}$ was added for an additional $48 \mathrm{~h}$. When cells were incubated in the absence of DAPT, $0.05 \%$ dimethyl sulfoxide (DMSO) was added to the medium. Finally, cells were stored at $-20^{\circ} \mathrm{C}$ for protein extraction.

\section{Proliferation Assay}

To evaluate the role of the Notch pathway in the proliferation of granulosa cell tumor line, KGN cells were incubated for $48 \mathrm{~h}$ either in the presence of DAPT, an inhibitor of the $\gamma$-secretase complex, or in the presence of its diluent, $0.05 \%$ DMSO. The proliferation was evaluated with increasing DAPT concentrations $(10,20$, and $30 \mu \mathrm{M})$ that have been demonstrated to be nontoxic in cultured cells $[28,33,34]$. For the assay, tritiated thymidine $(0.4$ $\mu \mathrm{Ci} /$ well, final specific activity $1.2 \mathrm{Ci} / \mathrm{mmol}$; NE027E; Perkin Elmer) was added to the culture $24 \mathrm{~h}$ after the stimulus. After an additional $24 \mathrm{~h}$, cells $(1 \times$ $10^{5} /$ well in a 96 -well plate) were harvested by vacuum aspiration onto glass fiber filters, which were washed $(5 \mathrm{sec} / \mathrm{wash})$ and dried with 1 volume of ethanol using a multiwell harvester [35]. Filters were allowed to dry and then transferred to vials containing scintillation cocktail (Optiphase HiSafe 3 scintillation liquid; Wallac). Radioactivity was counted in a scintillation counter (Tri-Carb 1600TR; efficiency 66.29\%; Packard).

\section{Cell Viability}

The number of viable cells following treatment with either different concentrations of DAPT or the PI3K inhibitor LY294002 was assessed using the Cell Titer 96AQueous One solution cell proliferation assay (MTS assay; Promega Corp.). Cells $\left(1 \times 10^{4} /\right.$ well $)$ were seeded in a 96-well culture plate, maintained for $24 \mathrm{~h}$ in DMEM containing $10 \% \mathrm{FBS}$, and incubated for $48 \mathrm{~h}$ in DMEM:F12 containing 2\% FBS with DAPT $(10,20$, and $30 \mu \mathrm{M})$ or LY294002 $(5,15$, and $25 \mu \mathrm{M})$. A volume of $20 \mu \mathrm{l}$ of $2-\left(4^{\prime}, 5^{\prime}\right.$-dimethyl-2'-thiazolyl)-3-(4" sulfophenyl) (MTS) solution was added to each well; the MTS tetrazolium compound was reduced by reduced nicotinamide adenine dinucleotide phosphate or reduced nicotinamide adenine dinucleotide produced by dehydrogenase enzymes in metabolically active cells into a colored, soluble formazan product. The plate was kept for $3 \mathrm{~h}$ in a $\mathrm{CO}_{2}$ incubator, and the absorbance at $490 \mathrm{~nm}$ was recorded with a 96-well plate ELISA reader (Thermo Scientific).

\section{Radioimmunoassay for Progesterone and Estradiol}

KGN cells $\left(1 \times 10^{5}\right.$ cells/well $)$ were precultured in 24 -well plates with DMEM:F12 containing 10\% FBS for $48 \mathrm{~h}$. The medium was changed to DMEM:F12 containing 2\% FBS and $100 \mathrm{nM}$ of androstenedione (a substrate for P450arom), and either DMSO $0.05 \%$ or DAPT $20 \mu \mathrm{M}$ was added to the culture medium. After $48 \mathrm{~h}$ culture, the supernatant of the culture medium was collected for the determination of steroid levels and stored at $-20^{\circ} \mathrm{C}$ until the assay. Progesterone and estradiol were measured using specific antibodies supplied by Dr. G.D. Niswender (Animal Reproduction and Biotechnology Laboratory, Colorado State University, Fort Collins, CO). Under these conditions, the intra-assay and interassay variations were $8.0 \%$ and $14.2 \%$ for progesterone and $7.2 \%$ and $12.5 \%$ for estradiol, respectively. The detection limit of the radioimmunoassay (RIA) for both steroids was $25 \mathrm{pg}$.

\section{Western Blot Analysis}

For Western blot analysis, hGCs and KGN cells were lysed in homogenization buffer containing $20 \mathrm{mM}$ Tris-HCl pH 8, $137 \mathrm{mM} \mathrm{NaCl}$, $1 \%$ Nonidet P-40, and $10 \%$ glycerol, supplemented with protease inhibitors ( $0.5 \mathrm{mM}$ phenylmethylsulfonyl fluoride, $0.025 \mathrm{mM} \mathrm{N}$-CBZ-L-phenylalanine chloromethyl ketone, $0.025 \mathrm{mM} \mathrm{N}$-p-tosyl-lysine chloromethyl ketone, and $0.025 \mathrm{mM}$ L-1-tosylamide-2-phenyl-ethylchloromethyl ketone) and phosphatase inhibitors ( $25 \mathrm{mM}$ sodium fluoride, $0.2 \mathrm{mM}$ sodium orthovanadate, and 10 $\mathrm{mM} \beta$-glycerophosphate). Samples were centrifuged at $4^{\circ} \mathrm{C}$ for $10 \mathrm{~min}$ at $10000 \times g$ and the resulting pellets were discarded. Protein concentration in the supernatant was measured by the Bradford assay. After boiling for $5 \mathrm{~min}, 20 \mu \mathrm{g}$ of protein was applied to an SDS-polyacrylamide gel (12\%-15\%) and electrophoresis was performed at $25 \mathrm{~mA}$ for $1.5 \mathrm{~h}$. The resolved proteins were transferred for $2 \mathrm{~h}$ onto nitrocellulose membranes. The blot was preincubated in blocking buffer (5\% nonfat milk, $0.05 \%$ Tween-20 in $20 \mathrm{mM} \mathrm{TBS} \mathrm{pH} \mathrm{8.0)} \mathrm{for}$ $1 \mathrm{~h}$ at room temperature and incubated with appropriate primary antibodies (NOTCH1 [1:400], NOTCH4 [1:400], JAGGED1 [1:200], PARP [1:200], BAX [1:200], BCL2 [1:200], BCLX [1:200], FAS [1:200], FASL [1:100], caspase 8 [1:200], AKT [1:5000], p-AKT [1:400], and PTEN [1:1000]) in blocking buffer overnight at $4^{\circ} \mathrm{C}$. The blots were then incubated with anti-rabbit or anti-mouse secondary antibodies conjugated with horseradish peroxidase (1:1000) and finally detected by chemiluminescence and autoradiography using $\mathrm{x}$-ray film. Protein loading was normalized by reprobing the same blots with antibody against actin B band. 

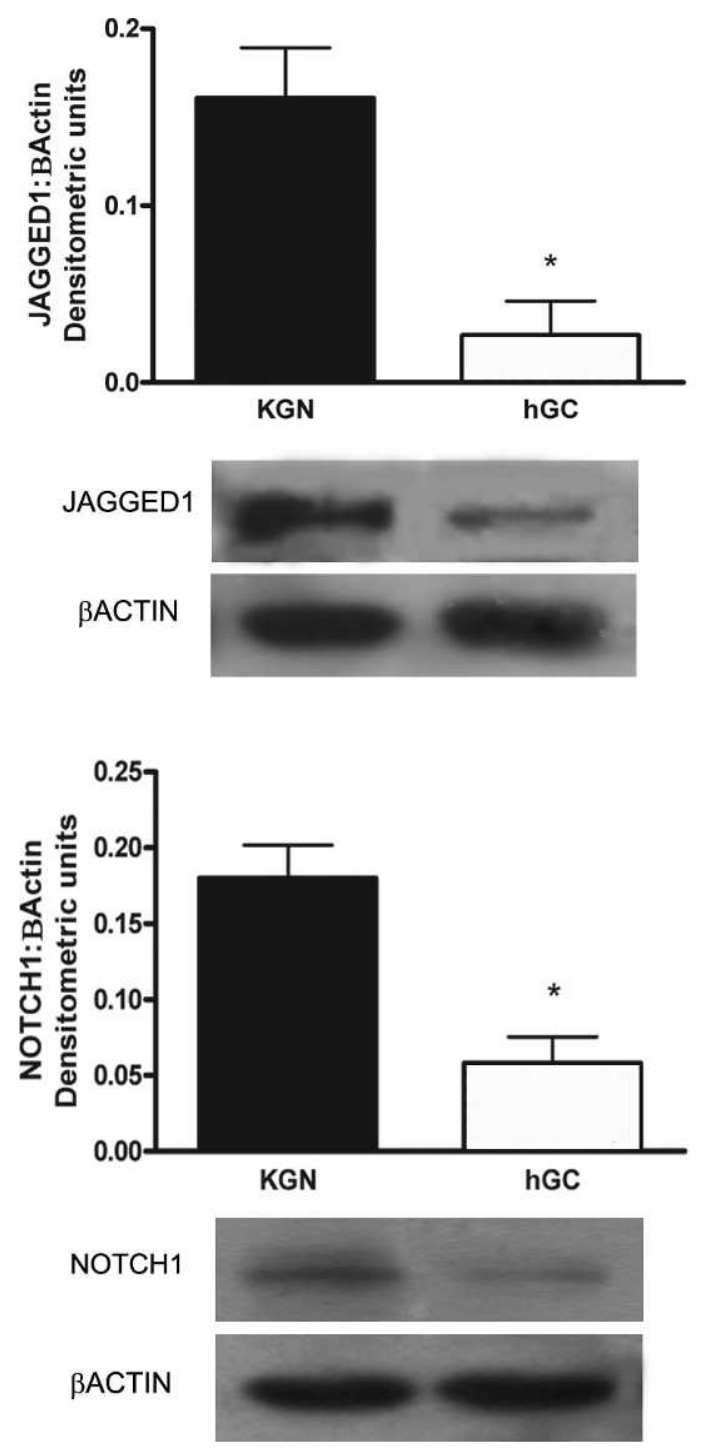

FIG. 1. Expression of JAGGED1, DLL4, NOTCH1, and NOTCH4 was assessed by Western blot using protein extracts of KGN cells $(\mathrm{n}=10)$ and hGCs obtained from follicular fluid of women subjected to ART $(n=9)$. The hGCs and KGN cells were lysed in homogenization buffer, protein concentration was determined, and $20 \mu \mathrm{g}$ was applied to a SDS-polyacrylamide gel. Representative bands are shown. Values are expressed as mean \pm SEM. *Indicates a value significantly different, $P<0.05$.

\section{Data Analysis}

Statistical analysis was carried out using GraphPad Prism software. All experiments were performed at least three times and the conditions were performed in triplicate.

Experiments were analyzed with Student $t$-test when two variables were involved or with one-way ANOVA following Tukey or Dunnett as posttest when three or more variables were concerned.

Data are expressed as means \pm SEM of pooled results obtained from different independent experiments. Representative gels are shown in the figures. Values of $P<0.05$ were considered significant.

\section{RESULTS}

\section{Analysis of JAGGED1, DLL4, NOTCH1, and NOTCH4 Expression in hGCs and KGN Cells}

The expression of JAGGED1, DLL4, NOTCH1, and NOTCH4 in KGN cells was studied by Western blot. We used hGCs obtained from patients subjected to ART and KGN cells to compare the levels of expression of these members. Tumor cells showed a significant higher expression of JAGGED 1 (0.16 \pm 0.03 arbitrary units) than hGCs (0.03 \pm
0.02 , arbitrary units $P<0.001)$. Similar results were obtained for NOTCH1 and NOTCH4 (NOTCH1, KGN $0.18 \pm 0.002$ vs. hGCs $0.06 \pm 0.02$ arbitrary units, $P<0.05$; NOTCH4, KGN $0.64 \pm 0.05$ vs. hGCs $0.34 \pm 0.02$ arbitrary units, $P<$ $0.001)$. The ligand DLL4 was observed in KGN cells but was not detected in hGCs (Fig. 1).

\section{Effects of DAPT on KGN Cell Proliferation}

To study the role of the Notch system in granulosa tumor cells proliferation, we used DAPT, an inhibitor of the $\gamma$ secretase complex. When KGN cells were incubated for $48 \mathrm{~h}$ in the presence of increasing concentrations of DAPT $(10,20$, and $30 \mu \mathrm{M}$ ), cell proliferation decreased, $20 \mu \mathrm{M}$ being the lowest concentration (34\% of decrease) at which we detected a significant difference in comparison to controls (no addition of DAPT) (control $1989 \pm 42$, DAPT $10 \mu \mathrm{M} 1852 \pm 104$, DAPT $20 \mu \mathrm{M} 1317 \pm 40$, DAPT $30 \mu \mathrm{M} 937 \pm 131 \mathrm{cpm}, P<0.01$; Fig. 2A). Similar results were obtained when the MTS assay was performed using the same concentrations of Notch inhibitor (Fig. 2B). For this reason, we chose $20 \mu \mathrm{M}$ as the 
IRUSTA ET AL.

A

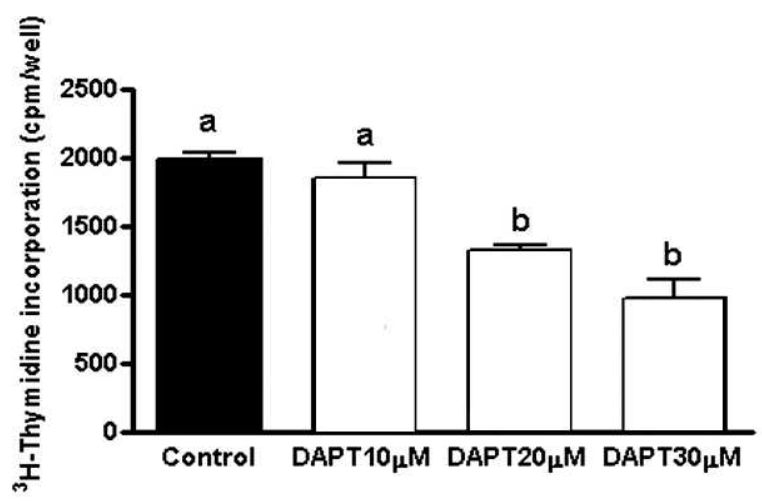

C

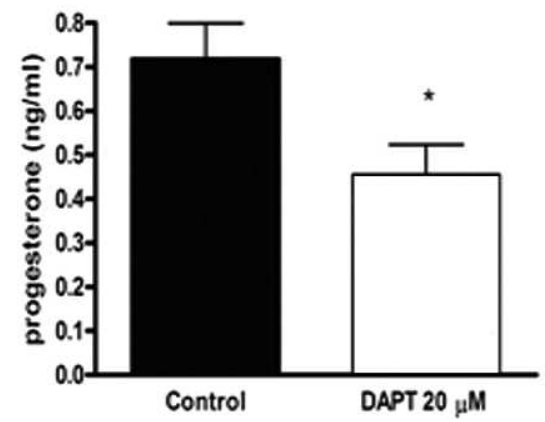

B

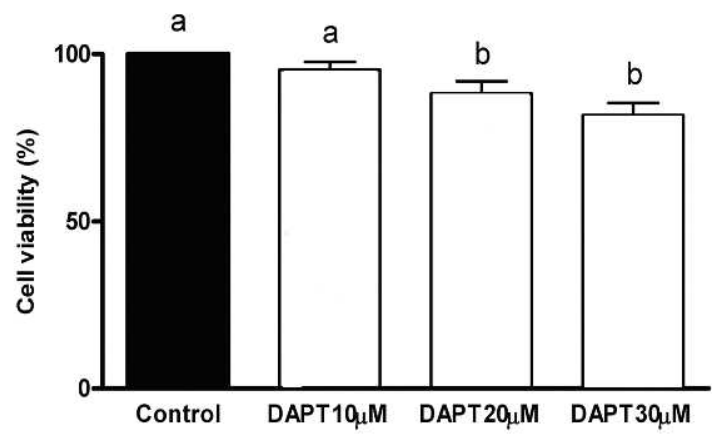

D

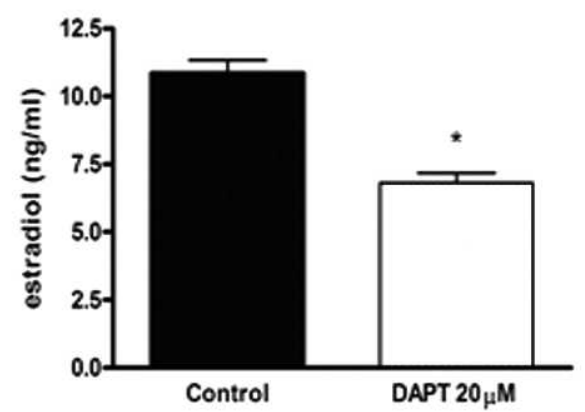

FIG. 2. Notch participation in KGN cell proliferation and steroidogenesis. KGN cell proliferation was determined by [ $\left.{ }^{3} \mathrm{H}\right]$ thymidine incorporation assay (A) [35] and cell viability was assessed by MTS assay (B) by following the manufacturer's instructions. Cells were incubated for $48 \mathrm{~h}$ in the presence of different concentrations of DAPT $(10,20$, and $30 \mu \mathrm{M})$. Different letters indicate significant differences compared to the control condition (absence of DAPT). a versus b, $P<0.01$. Levels of progesterone $(\mathbf{C})$ and estradiol $(\mathbf{D})$ in culture medium of KGN cells incubated with DAPT $20 \mu \mathrm{M}$ were determined by RIA. Values are shown as mean \pm SEM of $\mathrm{ng} / \mathrm{ml}$ of corresponding steroid in culture medium determined in at least three independent experiments. *Indicates significant differences with $P<0.05$ and $P<0.0001$ for progesterone and estradiol, respectively.

appropriate concentration to perform the subsequent experiments.

\section{Effect of Notch Inhibition on KGN Cell Steroidogenesis}

Progesterone and estradiol levels in culture medium of KGN cells were determined by RIA. We observed a significant decrease in the culture medium levels of progesterone in KGN cells cultured in the presence of DAPT $20 \mu \mathrm{M}$ for $48 \mathrm{~h}$ (control $0.72 \pm 0.08$ vs. DAPT $0.46 \pm 0.07 \mathrm{ng} / \mathrm{ml}, P<0.05$ ) as well as in the levels of estradiol (control $10.85 \pm 0.80$ vs. DAPT $6.82 \pm 0.35 \mathrm{ng} / \mathrm{ml}, P<0.0001)$ compared to control conditions (Fig. 2, C and D).

\section{Notch Involvement in the Apoptotic Pathway of KGN Cells}

To study the participation of Notch signaling in apoptotic parameters of KGN cells, we determined the levels of the cleaved fragment of PARP protein in KGN cells incubated with DAPT. Full-length PARP is $113 \mathrm{kDa}$ and, in the final step of apoptosis, it is cleaved by caspase 3 , generating an $89-\mathrm{kDa}$ fragment [36]. Interestingly, we observed a significant increase in the PARP cleaved fragment in cells incubated for $48 \mathrm{~h}$ with the Notch inhibitor compared to control cells (control $0.04 \pm$ 0.01 vs. DAPT $0.10 \pm 0.02$ arbitrary units, $P<0.05$; Fig. $3 \mathrm{~A}$ ).

\section{Contribution of Mitochondrial Proteins in DAPT-Induced Apoptosis}

We observed an increase in the proapoptotic proteins BAX (control $2.29 \pm 0.20$ vs. DAPT $3.27 \pm 0.25$ arbitrary units, $P$ $<0.01$ ) and BCLXs (control $5.0 \pm 0.98$ vs. DAPT $9.26 \pm$ 0.83 arbitrary units, $P<0.05$ ) when Notch activation was inhibited with DAPT in KGN cells (Fig. 3, B and C). However, when we analyzed the antiapoptotic proteins BCL2 and BCLX1 in KGN cells in the presence of DAPT, we detected no significant differences compared to controls (BCL2: control $21.55 \pm 1.46$ vs. DAPT $20.18 \pm 2.62$ arbitrary units; BCLXl: control $23.28 \pm 1.56$ vs. DAPT $29.71 \pm 3.36$ arbitrary units; Fig. 3, B and C). Therefore, the balance between BAX/BCL2 and $\mathrm{BCLXs} / \mathrm{BCLXl}$ was increased in KGN cells after the inhibition of Notch activation $(P<0.05$; Fig. $3, \mathrm{~B}$ and $\mathrm{C})$.

FIG. 3. Effect of Notch inhibition on apoptotic parameters of KGN cells. Different proteins associated with apoptotic processes were assessed by Western blot in KGN cells treated with $20 \mu \mathrm{M}$ of DAPT. A) Densitometric quantification of the cleaved fragment of PARP protein. B and C) Quantification of BAX, $\mathrm{BCL2}$, BCLXs, and BCLXI and the ratio between these proteins. D) FAS and FASL proteins belonging to the death-receptor pathway. E) The densitometric quantification of the cleaved fragment of caspase 8 after being activated by death receptors. *Indicates significant differences between control and DAPT incubation of KGN cells with $P<0.05$. All incubations were performed at least three times. 
B.

A.
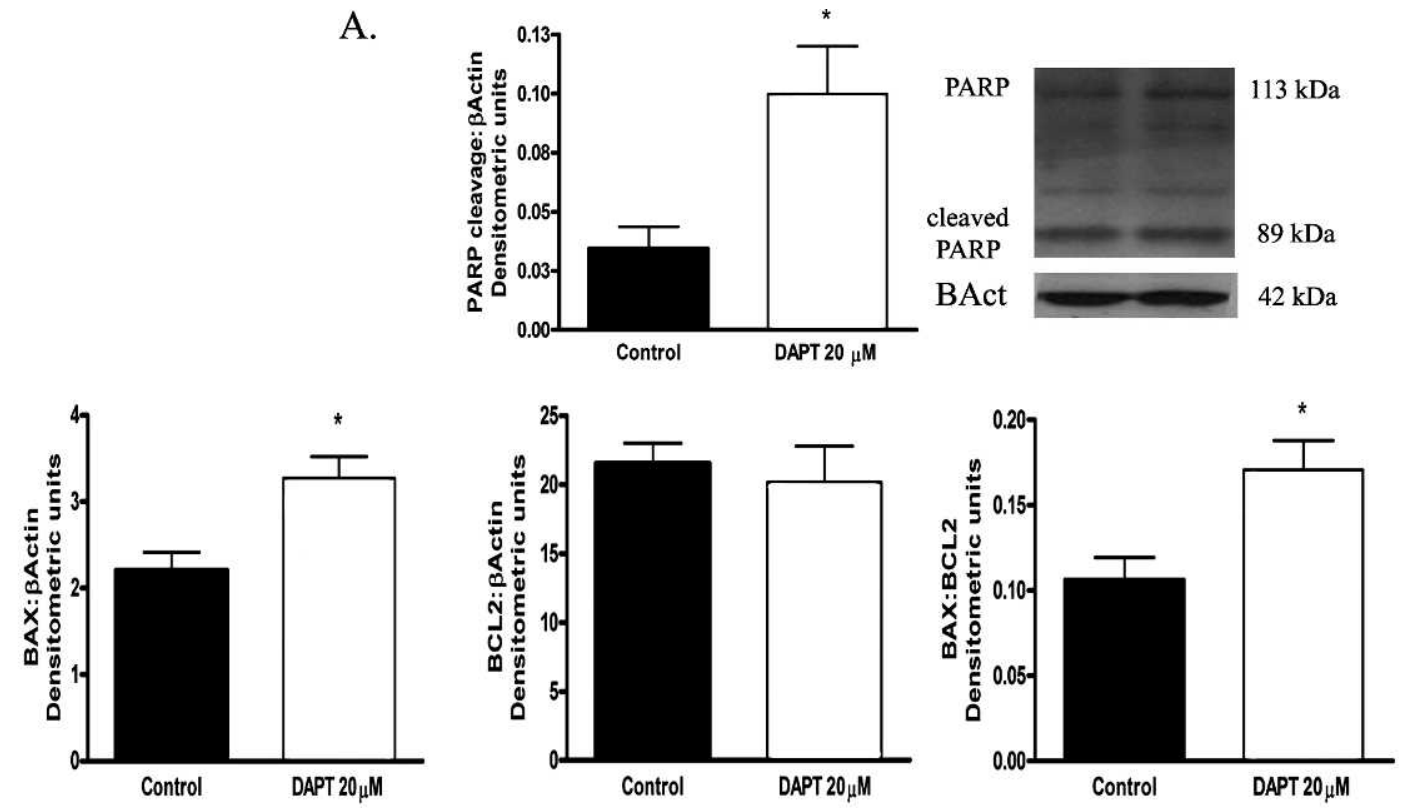
BAX
$21 \mathrm{kDa}$
BAct
$42 \mathrm{kDa}$
BCL2
$29 \mathrm{kDa}$
BAct
$42 \mathrm{kDa}$

C.
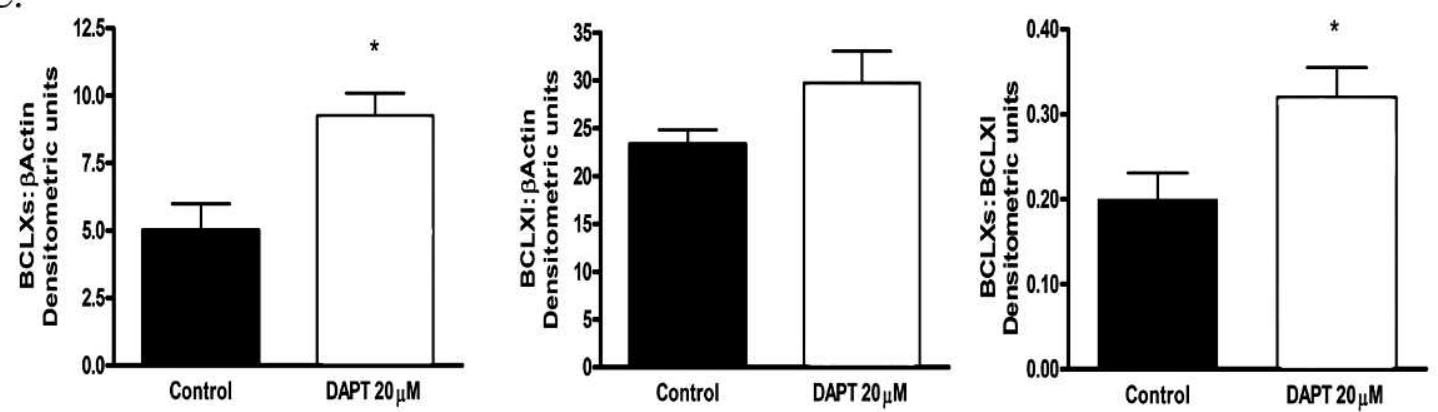

D.
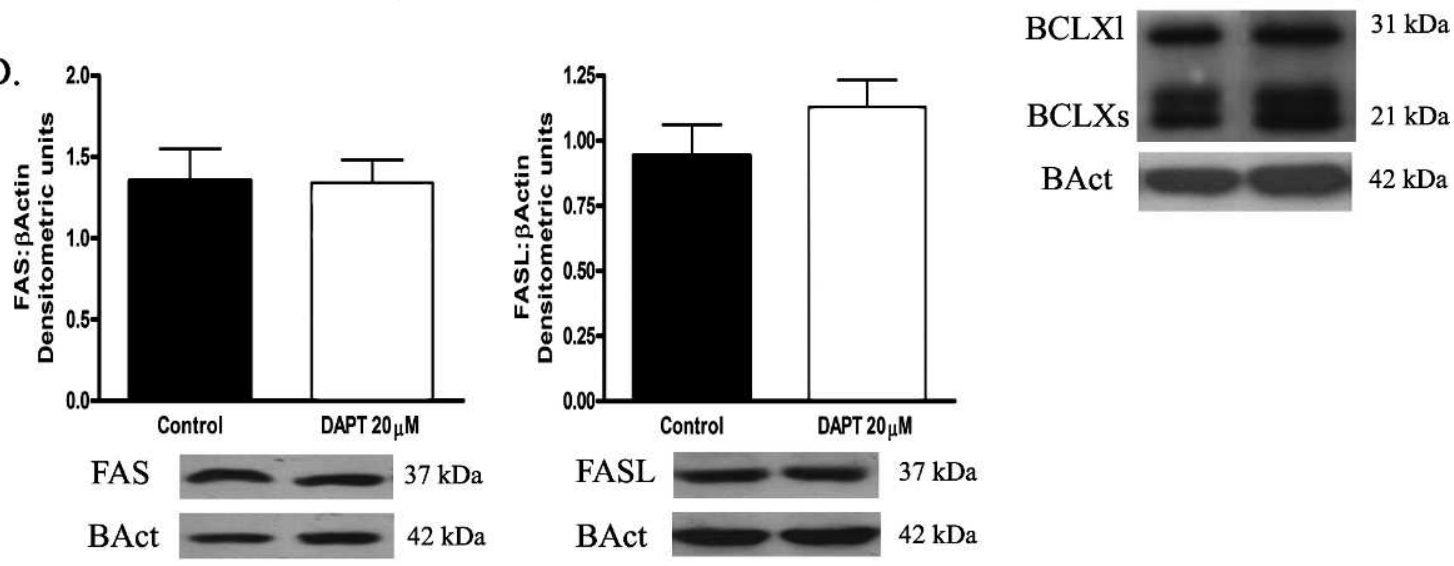

E.

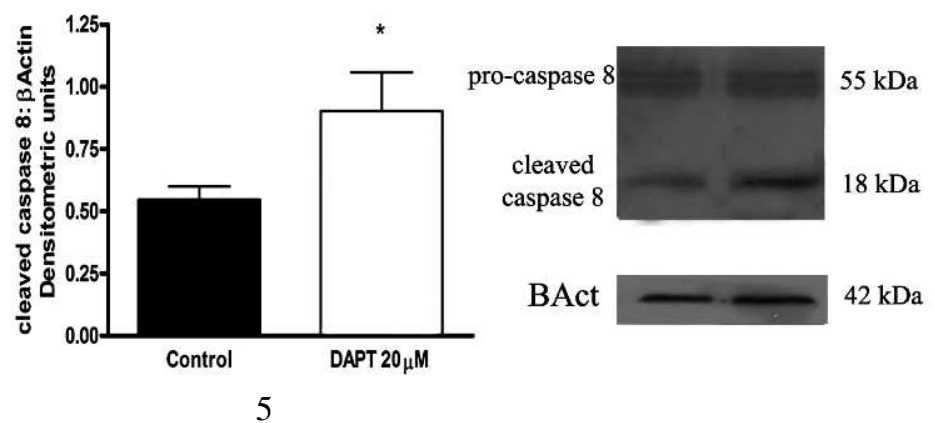

Article 9 
Involvement of Extrinsic Pathway Proteins in DAPT-Induced Apoptosis

The levels of FASL and FAS in KGN cells incubated with DAPT were not significantly different from those in control cells (FASL: control $0.94 \pm 0.12$ vs. DAPT $1.13 \pm 0.10$ arbitrary units; FAS: control $1.35 \pm 0.19$ vs. DAPT $1.34 \pm$ 0.14 arbitrary units; Fig. 3D). However, the active fragment of caspase 8 increased significantly in the presence of DAPT (control $0.55 \pm 0.05$ vs. DAPT $0.90 \pm 0.15$ arbitrary units; Fig. 3E).

\section{Effect of Notch Inhibition on the PI3K/AKT Intracellular Pathway}

To elucidate whether the PI3K/AKT pathway plays a role in KGN cell viability, we performed an MTS assay in the presence of LY294002, a PI3K inhibitor. As expected, this inhibitor decreased the percentage of viability of KGN cells. The decrease was 33\% at $15 \mu \mathrm{M}$ of LY294002, the lowest concentration at which we detected significant differences (data not shown). When we analyzed the levels of AKT phosphorylation in KGN cells in the presence of DAPT to investigate a possible interaction between these two pathways, we observed a significant decrease in the phospho-AKT/total AKT ratio in KGN cells incubated with the Notch inhibitor compared to control conditions (control $0.55 \pm 0.13$ vs. DAPT $0.16 \pm 0.02$ arbitrary units, $P<0.05$; Fig. $4 \mathrm{~A}$ ). Also, PTEN, the protein responsible for the dephosphorylation of the second messenger phosphatidylinositol 3,4,5-triphosphate, showed a marked increase in the presence of DAPT (control $0.03 \pm 0.004$ vs. DAPT $0.09 \pm 0.01$ arbitrary units; Fig. 4B).

\section{DISCUSSION}

The key findings of our study are the survival role of Notch in KGN, a granulosa tumor cell line representative of the adult form of GCTs, and the high expression of some Notch members in this cell line compared to hGCs from ART patients. We demonstrated for the first time that Notch inhibition decreases cell proliferation and steroidogenesis and increases several apoptotic markers in granulosa tumor cells. We also showed that the Notch pathway might crosstalk with PI3K/AKT signaling in this cell type.

The Notch system is highly pleiotropic and its effects have been demonstrated to be context dependent [13]. Members of this system have been associated with different types of tumors, and the relationship between some members of this system and epithelial ovarian cancer has been studied, but no information is available on GCTs. Choi et al. showed that JAGGED1 promotes proliferation and dissemination of epithelial ovarian cancer cells [37]. Hu et al. associated DLL4 with worse overall survival and described it as a proliferation- and angiogenesispromoting factor in epithelial ovarian tumor cells and tumorassociated endothelial cells [20]. Similarly, JAGGED1 promotes proliferation in epithelial ovarian cancer cell lines and is related to taxane resistance. In the present study, we found a differential expression of JAGGED1 and NOTCH1 and 4 receptors between KGN cells and hGCs obtained from ART patients. More studies are needed to demonstrate that Notch members would be potential therapeutic targets for this type of tumors. KGN cells might exhibit steroidogenesis similar to normal hGCs; however, they are likely to differ from normal granulosa cells in their proliferative potential because KGN is a tumor-derived cell line [38]. Also, hGCs are luteinized granulosa cells, whereas KGN cells seem to be close to an immature granulosa cell developmental stage [30]. However,
A

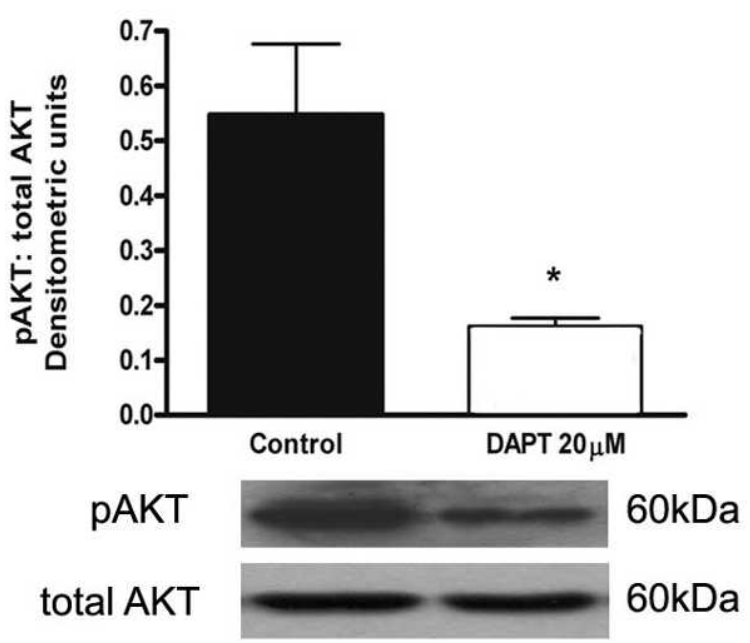

B
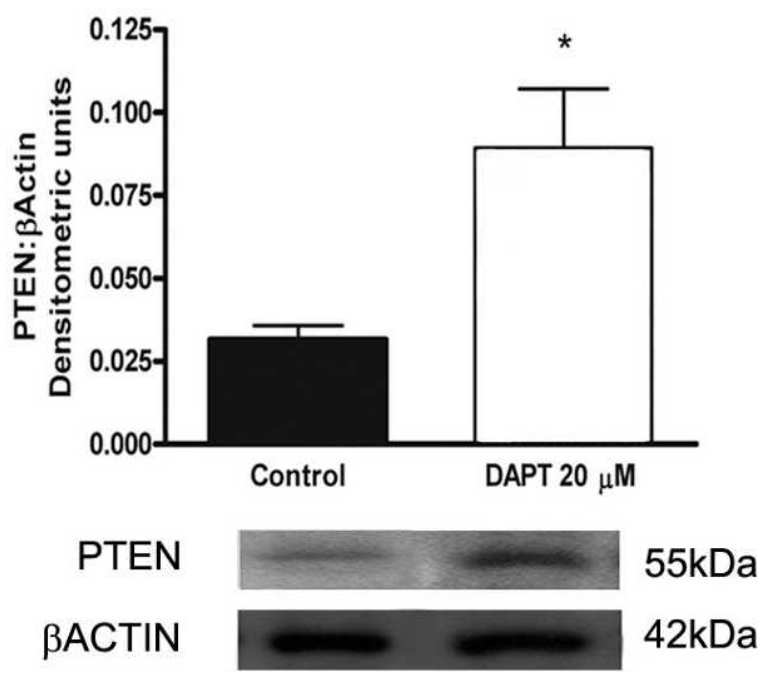

FIG. 4. Notch and PI3K/AKT signaling pathway. A) Levels of phosphorylated and total AKT. B) Levels of PTEN protein determined by Western blot in protein extracts of KGN cells incubated for $48 \mathrm{~h}$ in the presence or absence of $20 \mu \mathrm{M}$ of DAPT. The ratio between phosphorylated and total AKT is shown in the graph. ${ }^{*} P<0.05$.

right now, hGCs are the best available normal cells that can be used for comparison purposes.

Because this finding stimulated us to continue with the study of the Notch system in a granulosa tumor cell line, we used a $\gamma$-secretase complex inhibitor (DAPT) to inhibit Notch activation in KGN cells. Gamma-secretase inhibitors have been shown to be potent inhibitors of the Notch signaling pathway. In particular, DAPT has been widely used to perform studies in different types of tumor cell lines such as endometrial cells, breast cancer cells, gastric cancer cells, and some animal models [39-41]. In this study, the inhibition of the Notch system decreased proliferation and viability of the granulosa tumor cell line. This result agrees with other studies performed in tumor cell lines of different origins [33, 42, 43]. In cells of renal carcinoma using small interfering RNA (siRNA) targeting the different Notch receptors, it was established that the Notch promoting effect on proliferation was attributable to NOTCH1 [42]. More recently, in prostate cancer cells, Wang et al. demonstrated that down-regulation of NOTCH1 inhibits cell growth and induces apoptosis [28]. More precisely, in 
epithelial ovarian cancer cell lines, the down-regulation of JAGGED1 expression affected cell viability and induced apoptosis [19]. However, Notch opposing effects in tumor cells have also been described [13]. Regarding cell cyclerelated proteins, it is known that the Notch intracellular domain translocates into the nucleus, where it forms a complex with the members of the CBF 1/Su (H)/Lag 1 transcription factor family [12], and this complex mediates the transcription of target genes such as Hes-1, Hey, cyclin D, and p21waf1/cip1 to execute the downstream biological effects [44]. Further studies are required to clarify the involvement of Notch signaling in cell cycle-related genes.

Granulosa cells are the principal source of estradiol in ovarian tissue. Estrogen synthesis is essential for ovarian cyclicity and fertility and, in addition, estrogens are mitogenic factors for ovarian granulosa cells [35]. Several works have described the participation of steroid hormones, mainly estrogens, in ovarian carcinogenesis [45, 46]. Here, we observed a decrease in progesterone and estradiol synthesis in KGN cells when Notch activation was inhibited by DAPT. However, we cannot discard the possibility that this decrease in steroid synthesis is due to the lower KGN proliferation and viability observed in the presence of DAPT or because a direct action of Notch on the expression of steroidogenic enzymes is involved.

Notch has also been described as a tumor suppressor and this is thought to be a result of the crosstalk with other signaling pathways governing proliferation and apoptosis [13]. Because of the pivotal role of apoptosis in tumorigenesis, we studied the effect of DAPT on apoptosis parameters in KGN cells. As we described, DAPT induced the cleavage of PARP protein in KGN cell culture, indicating an increase in caspase 3 activity.

Furthermore, we demonstrated that this increase in apoptosis observed in granulosa tumor cells in the presence of DAPT is mediated by changes in the levels of the $b c l 2$ family of proteins as well as in caspase 8 activity. The BAX/BCL2 and BCLXs/BCLXl proapoptotic ratios were increased when Notch activation was inhibited, demonstrating an impaired function of mitochondria in these cells and the participation of the intrinsic apoptotic pathway in DAPT-induced apoptosis in KGN cells. The proapoptotic activity of $\mathrm{BH} 3$-interacting domain death agonist (BID) and BAX proteins has been recently confirmed in $\mathrm{KGN}$ cells by using the siRNA technique [47]. BAX expression has also been associated with apoptosis in ovarian cancer tissue, and patients expressing high levels of BAX in tumors have a significantly longer median survival than patients with low BAX expression [48, 49]. BCL2 is known to be overexpressed in many solid neoplasms, including ovarian cancer, contributing to neoplastic transformation and drug-resistant disease [50, 51]. Moreover, in ovarian cancer, the percentage and intensity of epithelial and stromal BCL2 staining decreases with tumor progression [52]. In particular, BCL2 is expressed in human GCTs, suggesting a role of this antiapoptotic factor in human granulosa cell pathobiology [53, 54]. These antecedents indicate the importance of these proteins in ovarian cancer development.

Related to pathways involved in DAPT-induced apoptosis in KGN cells, we also analyzed some members of the death receptor family. Although we detected no differences in the levels of the FAS/FASL system, we detected an increase in the cleavage of caspase 8 , indicating an involvement of this mechanism of apoptosis in KGN cells treated with DAPT. However, Nishi et al., who established the KGN cell line from an ovarian carcinoma, described that when these cells are exposed to FAS antibody with the addition of interferon- $\gamma$ to induce receptor-mediated cell death, the number of apoptotic cells increases dramatically [29]. These results demonstrate that this mechanism is active in these cells, in agreement with the importance of the FAS/FASL system in the apoptosis of granulosa cells in primary culture system $[55,56]$. Recently, it has been reported that TRAIL receptors are expressed in a vast majority of GCTs as well as in primary GCT cultures, and that this pathway is functional in this type of tumor cells. This functionality of TRAIL signaling has also been demonstrated for KGN cells [54]. Nonetheless, in the present study, we did not analyze other receptor systems like TNF and/or TRAIL, which also participate in death receptor apoptosis and could be involved in the DAPT-induced apoptosis in this cell line. Further studies are required to elucidate the precise role of these receptor systems in KGN cells.

Different reports have demonstrated the interaction between Notch signaling and PI3K/AKT pathways. In breast epithelial cancer cells, Notch signaling induces an autocrine signaling loop that activates AKT and is necessary for Notch-induced protection against apoptosis [27]. More recently, Wang et al. reported that, in prostate cancer cells, the down-regulation of NOTCH1 leads to the inhibition of cell growth mechanistically linked to down-regulation of AKT, suggesting that this protein is a downstream target of NOTCH1 signaling [28]. In addition, the PI3K/AKT pathway is frequently activated in ovarian cancer $[57,58]$. Here we showed that phosphorylation of AKT was inhibited in KGN cells treated with the Notch inhibitor DAPT. The Notch system and AKT pathway interact in different ways. In cells belonging to a type of acute lymphoblastic leukemia (T-ALL), inhibition of Notch signaling by a $\gamma-$ secretase inhibitor increases PTEN expression, resulting in a decrease in the activation of PI3K/AKT signaling [59]. Also, the existence of the NOTCH1-PI3K complex has been demonstrated in primary $\mathrm{T}$ cells in vitro, confirming the physical interaction of these two proteins [60]. A close relationship between NOTCH1 receptor and PTEN protein has also been well described in T-ALL leukemia cells by Palomero et al. [61]. Interestingly, they found that T-ALL- $\gamma-$ secretase inhibitor-sensitive cells show detectable levels of PTEN protein, whereas T-ALL- $\gamma$-secretase inhibitor-resistant cells show total absence or a marked decrease in this protein. They concluded that mutational loss of PTEN is associated with resistance to NOTCH1 inhibition in human T-ALL [61]. In the present work, we observed an increase in PTEN protein in KGN cells when the Notch pathway was inhibited. Lague et al. provided powerful evidence about the role of the dysregulation of the PI3K/AKT pathway in the pathogenesis of GCTs by means of a Ptenflox/flox, Amhr ${ }^{\text {cre/+ }}$ mouse model that developed GCTs [62]. Our results strengthen the hypothesis of an interaction between PI3K/AKT and Notch signaling, but further experiments are needed to deeply investigate this interaction.

In the present study, we provided the first evidence about the Notch system acting as a survival pathway in a FOXL2mutated granulosa tumor cell line (KGN) representative of the adult form of GCTs. We also showed a differential expression of some members of this signaling pathway between normal and KGN cells. However, we cannot discard the action of DAPT on other $\gamma$-secretase substrates.

In summary, our results demonstrate that Notch induces granulosa tumor cell proliferation and decreases apoptosismediated cell death. Also, Notch might be interacting with the PI3K/AKT signaling pathway, intensifying the survival role of Notch in this type of tumor. 


\section{ACKNOWLEDGMENT}

We thank Diana Bas (IByME-CONICET) for technical assistance.

\section{REFERENCES}

1. Farkkila A, Pihlajoki M, Tauriala H, Butzow R, Leminen A, Unkila-Kallio L, Heikinheimo M, Anttonen M. Serum vascular endothelial growth factor A (VEGF) is elevated in patients with ovarian granulosa cell tumor (GCT), and VEGF inhibition by bevacizumab induces apoptosis in GCT in vitro. $\mathrm{J}$ Clin Endocrinol Metab 2011; 96:E1973-E1981.

2. Shah SP, Kobel M, Senz J, Morin RD, Clarke BA, Wiegand KC, Leung G, Zayed A, Mehl E, Kalloger SE, Sun M, Giuliany R, et al. Mutation of FOXL2 in granulosa-cell tumors of the ovary. N Engl J Med 2009; 360: 2719-2729.

3. Kobel M, Gilks CB, Huntsman DG. Adult-type granulosa cell tumors and FOXL2 mutation. Cancer Res 2009; 69:9160-9162.

4. Kalfa N, Veitia RA, Benayoun BA, Boizet-Bonhoure B, Sultan C. The new molecular biology of granulosa cell tumors of the ovary. Genome Med 2009; 1:81.1-81.4

5. Jamieson S, Butzow R, Andersson N, Alexiadis M, Unkila-Kallio L, Heikinheimo M, Fuller PJ, Anttonen M. The FOXL2 C134W mutation is characteristic of adult granulosa cell tumors of the ovary. Mod Pathol 2010; 23:1477-1485.

6. Geiersbach KB, Jarboe EA, Jahromi MS, Baker CL, Paxton CN, Tripp SR, Schiffman JD. FOXL2 mutation and large-scale genomic imbalances in adult granulosa cell tumors of the ovary. Cancer Genet 2011; 204: 596-602.

7. Caburet S, Georges A, L'Hote D, Todeschini AL, Benayoun BA, Veitia RA. The transcription factor FOXL2: at the crossroads of ovarian physiology and pathology. Mol Cell Endocrinol 2012; 356:55-64.

8. Kim T, Sung CO, Song SY, Bae DS, Choi YL. FOXL2 mutation in granulosa-cell tumours of the ovary. Histopathology 2010; 56:408-410.

9. Kim MS, Hur SY, Yoo NJ, Lee SH. Mutational analysis of FOXL2 codon 134 in granulosa cell tumour of ovary and other human cancers. J Pathol 2010; 221:147-152.

10. Al Agha OM, Huwait HF, Chow C, Yang W, Senz J, Kalloger SE, Huntsman DG, Young RH, Gilks CB. FOXL2 is a sensitive and specific marker for sex cord-stromal tumors of the ovary. Am J Surg Pathol 2011; 35:484-494.

11. Hes O, Vanecek T, Petersson F, Grossmann P, Hora M, Perez Montiel DM, Steiner P, Dvorak M, Michal M. Mutational analysis (c.402C $>$ G) of the FOXL2 gene and immunohistochemical expression of the FOXL2 protein in testicular adult type granulosa cell tumors and incompletely differentiated sex cord stromal tumors. Appl Immunohistochem Mol Morphol 2011; 19:347-351.

12. Kopan R, Ilagan MX. The canonical Notch signaling pathway: unfolding the activation mechanism. Cell 2009; 137:216-233.

13. Ranganathan P, Weaver KL, Capobianco AJ. Notch signalling in solid tumours: a little bit of everything but not all the time. Nat Rev Cancer 2011; 11:338-351.

14. Takeshita K, Satoh M, Ii M, Silver M, Limbourg FP, Mukai Y, Rikitake Y, Radtke F, Gridley T, Losordo DW, Liao JK. Critical role of endothelial Notch1 signaling in postnatal angiogenesis. Circ Res 2007; 100:70-78.

15. Reedijk M, Odorcic S, Chang L, Zhang H, Miller N, McCready DR, Lockwood G, Egan SE. High-level coexpression of JAG1 and NOTCH1 is observed in human breast cancer and is associated with poor overall survival. Cancer Res 2005; 65:8530-8537.

16. Rizzo P, Miao H, D'Souza G, Osipo C, Song LL, Yun J, Zhao H, Mascarenhas J, Wyatt D, Antico G, Hao L, Yao K, et al. Cross-talk between notch and the estrogen receptor in breast cancer suggests novel therapeutic approaches. Cancer Res 2008; 68:5226-5235.

17. Santagata S, Demichelis F, Riva A, Varambally S, Hofer MD, Kutok JL, Kim R, Tang J, Montie JE, Chinnaiyan AM, Rubin MA, Aster JC. JAGGED1 expression is associated with prostate cancer metastasis and recurrence. Cancer Res 2004; 64:6854-6857.

18. Bell DaTE. Integrated genomic analyses of ovarian carcinoma. Nature 2011; 474:609-615.

19. Steg AD, Katre AA, Goodman B, Han HD, Nick AM, Stone RL, Coleman RL, Alvarez RD, Lopez-Berestein G, Sood AK, Landen CN. Targeting the notch ligand JAGGED1 in both tumor cells and stroma in ovarian cancer. Clin Cancer Res 2011; 17:5674-5685.

20. Hu W, Lu C, Dong HH, Huang J, Shen DY, Stone RL, Nick AM, Shahzad MM, Mora E, Jennings NB, Lee SJ, Roh JW, et al. Biological roles of the Delta family Notch ligand Dll4 in tumor and endothelial cells in ovarian cancer. Cancer Res 2011; 71:6030-6039.
21. Franke TF, Hornik CP, Segev L, Shostak GA, Sugimoto C. PI3K/Akt and apoptosis: size matters. Oncogene 2003; 22:8983-8998.

22. Cantley LC, Neel BG. New insights into tumor suppression: PTEN suppresses tumor formation by restraining the phosphoinositide 3-kinase/ AKT pathway. Proc Natl Acad Sci U S A 1999; 96:4240-4245.

23. Yang X, Fraser M, Moll UM, Basak A, Tsang BK. Akt-mediated cisplatin resistance in ovarian cancer: modulation of p53 action on caspasedependent mitochondrial death pathway. Cancer Res 2006; 66:3126-3136.

24. Altomare DA, Wang HQ, Skele KL, De Rienzo A, Klein-Szanto AJ, Godwin AK, Testa JR. AKT and mTOR phosphorylation is frequently detected in ovarian cancer and can be targeted to disrupt ovarian tumor cell growth. Oncogene 2004; 23:5853-5857.

25. Woenckhaus J, Steger K, Sturm K, Munstedt K, Franke FE, Fenic I. Prognostic value of PIK3CA and phosphorylated AKT expression in ovarian cancer. Virchows Arch 2007; 450:387-395.

26. Kolasa IK, Rembiszewska A, Felisiak A, Ziolkowska-Seta I, Murawska M, Moes J, Timorek A, Dansonka-Mieszkowska A, Kupryjanczyk J. PIK3CA amplification associates with resistance to chemotherapy in ovarian cancer patients. Cancer Biol Ther 2009; 8:21-26.

27. Meurette O, Stylianou S, Rock R, Collu GM, Gilmore AP, Brennan K. Notch activation induces Akt signaling via an autocrine loop to prevent apoptosis in breast epithelial cells. Cancer Res 2009; 69:5015-5022.

28. Wang Z, Li Y, Ahmad A, Banerjee S, Azmi AS, Kong D, Wojewoda C, Miele L, Sarkar FH. Down-regulation of Notch-1 is associated with Akt and FoxM1 in inducing cell growth inhibition and apoptosis in prostate cancer cells. J Cell Biochem 2011; 112:78-88.

29. Nishi Y, Yanase T, Mu Y, Oba K, Ichino I, Saito M, Nomura M, Mukasa C, Okabe T, Goto K, Takayanagi R, Kashimura Y, et al. Establishment and characterization of a steroidogenic human granulosa-like tumor cell line, $\mathrm{KGN}$, that expresses functional follicle-stimulating hormone receptor. Endocrinology 2001; 142:437-445.

30. Imai M, Muraki M, Takamatsu K, Saito H, Seiki M, Takahashi Y. Spontaneous transformation of human granulosa cell tumours into an aggressive phenotype: a metastasis model cell line. BMC Cancer 2008; 8: 319.

31. Dain LB, Bley MA, Baranao JL, Tesone M. Evidence for the production of a growth-inhibitory factor by human granulosa-luteal cells. Mol Reprod Dev 1993; 36:159-163.

32. Dain L, Guerrero H, Polak DF, Tesone M. Regulation of the steroidogenic response of cultured human granulosa cells: effects of serum and 25hydroxycholesterol. Fertil Steril 1995; 64:335-339.

33. Wang Z, Li Y, Banerjee S, Kong D, Ahmad A, Nogueira V, Hay N, Sarkar FH. Down-regulation of Notch-1 and Jagged-1 inhibits prostate cancer cell growth, migration and invasion, and induces apoptosis via inactivation of Akt, mTOR, and NF-kappaB signaling pathways. J Cell Biochem 2010; 109:726-736.

34. Fan RH, Li J, Wu N, Chen PS. Late SV40 factor: a key mediator of Notch signaling in human hepatocarcinogenesis. World J Gastroenterol 2011; 17: 3420-3430.

35. Bley MA, Saragueta PE, Baranao JL. Concerted stimulation of rat granulosa cell deoxyribonucleic acid synthesis by sex steroids and folliclestimulating hormone. J Steroid Biochem Mol Biol 1997; 62:11-19.

36. Rosen A, Casciola-Rosen L. Macromolecular substrates for the ICE-like proteases during apoptosis. J Cell Biochem 1997; 64:50-54.

37. Choi JH, Park JT, Davidson B, Morin PJ, Shih I, Wang TL. Jagged-1 and Notch3 juxtacrine loop regulates ovarian tumor growth and adhesion. Cancer Res 2008; 68:5716-5723.

38. Iwase A, Goto M, Harata T, Takigawa S, Nakahara T, Suzuki K, Manabe S, Kikkawa F. Insulin attenuates the insulin-like growth factor-I (IGF-I)Akt pathway, not IGF-I-extracellularly regulated kinase pathway, in luteinized granulosa cells with an increase in PTEN. J Clin Endocrinol Metab 2009; 94:2184-2191.

39. Hernandez F, Peluffo MC, Stouffer RL, Irusta G, Tesone M. Role of the DLL4-NOTCH system in PGF2alpha-induced luteolysis in the pregnant rat. Biol Reprod 2011; 84:859-865.

40. Mori M, Miyamoto T, Yakushiji H, Ohno S, Miyake Y, Sakaguchi T, Hattori M, Hongo A, Nakaizumi A, Ueda M, Ohno E. Effects of N-[N-(3, 5-difluorophenacetyl-L:-alanyl)]-S-phenylglycine t-butyl ester (DAPT) on cell proliferation and apoptosis in Ishikawa endometrial cancer cells. Hum Cell 2012; 25(1):9-15.

41. Guo S, Gonzalez-Perez RR. Notch, IL-1 and leptin crosstalk outcome (NILCO) is critical for leptin-induced proliferation, migration and VEGF/ VEGFR-2 expression in breast cancer. PLoS One 2011; 6:e21467.

42. Sjolund J, Johansson M, Manna S, Norin C, Pietras A, Beckman S, Nilsson E, Ljungberg B, Axelson H. Suppression of renal cell carcinoma growth by inhibition of Notch signaling in vitro and in vivo. J Clin Invest 2008; 118:217-228. 
43. Eliasz S, Liang S, Chen Y, De Marco MA, Machek O, Skucha S, Miele L, Bocchetta M. Notch-1 stimulates survival of lung adenocarcinoma cells during hypoxia by activating the IGF-1R pathway. Oncogene 2010;29: 2488-2498.

44. Miele L, Golde T, Osborne B. Notch signaling in cancer. Curr Mol Med 2006; 6:905-918.

45. Clinton GM, Hua W. Estrogen action in human ovarian cancer. Crit Rev Oncol Hematol 1997; 25:1-9.

46. Emons G, Kavanagh JJ. Hormonal interactions in ovarian cancer. Hematol Oncol Clin North Am 1999; 13:145-161, ix.

47. Sai T, Matsuda F, Goto Y, Maeda A, Sugimoto M, Gao HM, Kabir AK, Li JY, Manabe N. Effect of RNA interference of BID and BAX mRNAs on apoptosis in granulosa cell-derived KGN cells. J Reprod Dev 2012; 58: 112-116.

48. Schuyer M, van der Burg ME, Henzen-Logmans SC, Fieret JH, Klijn JG, Look MP, Foekens JA, Stoter G, Berns EM. Reduced expression of BAX is associated with poor prognosis in patients with epithelial ovarian cancer: a multifactorial analysis of TP53, p21, BAX and BCL-2. Br J Cancer 2001; 85:1359-1367.

49. Baekelandt M, Holm R, Nesland JM, Trope CG, Kristensen GB. Expression of apoptosis-related proteins is an independent determinant of patient prognosis in advanced ovarian cancer. J Clin Oncol 2000; 18: 3775-3781.

50. Wang J, Zhou JY, Zhang L, Wu GS. Involvement of MKP-1 and Bcl-2 in acquired cisplatin resistance in ovarian cancer cells. Cell Cycle 2009; 8: 3191-3198.

51. Placzek WJ, Wei J, Kitada S, Zhai D, Reed JC, Pellecchia M. A survey of the anti-apoptotic Bcl-2 subfamily expression in cancer types provides a platform to predict the efficacy of Bcl-2 antagonists in cancer therapy. Cell Death Dis 2010; 1:e40.

52. Anderson NS, Turner L, Livingston S, Chen R, Nicosia SV, Kruk PA. Bcl-2 expression is altered with ovarian tumor progression: an immunohistochemical evaluation. J Ovarian Res 2009; 2:16.

53. Kyronlahti A, Ramo M, Tamminen M, Unkila-Kallio L, Butzow R, Leminen A, Nemer M, Rahman N, Huhtaniemi I, Heikinheimo M,
Anttonen M. GATA-4 regulates Bcl-2 expression in ovarian granulosa cell tumors. Endocrinology 2008; 149:5635-5642.

54. Kyronlahti A, Kauppinen M, Lind E, Unkila-Kallio L, Butzow R, Klefstrom J, Wilson DB, Anttonen M, Heikinheimo M. GATA4 protects granulosa cell tumors from TRAIL-induced apoptosis. Endocr Relat Cancer 2010; 17:709-717.

55. Quirk SM, Cowan RG, Joshi SG, Henrikson KP. Fas antigen-mediated apoptosis in human granulosa/luteal cells. Biol Reprod 1995; 52:279-287.

56. Hakuno N, Koji T, Yano T, Kobayashi N, Tsutsumi O, Taketani Y, Nakane PK. Fas/APO-1/CD95 system as a mediator of granulosa cell apoptosis in ovarian follicle atresia. Endocrinology 1996; 137:1938-1948.

57. Shayesteh L, Lu Y, Kuo WL, Baldocchi R, Godfrey T, Collins C, Pinkel D, Powell B, Mills GB, Gray JW. PIK3CA is implicated as an oncogene in ovarian cancer. Nat Genet 1999; 21:99-102.

58. Huang J, Zhang L, Greshock J, Colligon TA, Wang Y, Ward R, Katsaros D, Lassus H, Butzow R, Godwin AK, Testa JR, Nathanson KL, et al. Frequent genetic abnormalities of the PI3K/AKT pathway in primary ovarian cancer predict patient outcome. Genes Chromosomes Cancer 2011; 50:606-618.

59. Nair P, Somasundaram K, Krishna S. Activated Notch1 inhibits p53induced apoptosis and sustains transformation by human papillomavirus type 16 E6 and E7 oncogenes through a PI3K-PKB/Akt-dependent pathway. J Virol 2003; 77:7106-7112.

60. Sade H, Krishna S, Sarin A. The anti-apoptotic effect of Notch-1 requires p56lck-dependent, Akt/PKB-mediated signaling in T cells. J Biol Chem 2004; 279:2937-2944.

61. Palomero T, Sulis ML, Cortina M, Real PJ, Barnes K, Ciofani M, Caparros E, Buteau J, Brown K, Perkins SL, Bhagat G, Agarwal AM, et al. Mutational loss of PTEN induces resistance to NOTCH1 inhibition in T-cell leukemia. Nat Med 2007; 13:1203-1210.

62. Lague MN, Paquet M, Fan HY, Kaartinen MJ, Chu S, Jamin SP, Behringer RR, Fuller PJ, Mitchell A, Dore M, Huneault LM, Richards JS, et al. Synergistic effects of Pten loss and WNT/CTNNB1 signaling pathway activation in ovarian granulosa cell tumor development and progression. Carcinogenesis 2008; 29:2062-2072. 